\title{
A Joint Segregation Analysis of the Inheritance of Fertility Restoration for Cytoplasmic Male Sterility in Pepper
}

\author{
Bingqiang Wei \\ College of Horticulture, Gansu Agricultural University, 1 Yingmeng Village, Anning District, \\ Lanzhou 730070, China
}

Lanlan Wang

Vegetable Institute, Gansu Academy of Agricultural Sciences, 1 Nongkeyuan New Village, Lanzhou 730070, China

Paul W. Bosland

College of Agriculture, Consumer, and Environmental Sciences, New Mexico State University, P.O. Box 30003, Las Cruces, NM 88001

Gaoyuan Zhang

College of Horticulture, Gansu Agricultural University, 1 Yingmeng Village, Anning District, Lanzhou 730070, China

\author{
Ru Zhang \\ Vegetable Institute, Gansu Academy of Agricultural Sciences, 1 Nongkeyuan New Village, Lanzhou \\ 730070, China
}

\begin{abstract}
Additional Index words. Capsicum annuum, CMS, fertility restoration, genetics, major gene plus polygene
Abstract. A cytoplasmic male sterility (CMS) system is one of the most efficient ways to produce $F_{1}$ hybrid seeds in pepper (Capsicum annuum). Restorer-of-fertility $(R f)$ genes are a critical component within the $C M S / R f$ system. The inheritance of $R f$ genes in pepper by joint segregation analysis was examined. The inheritance of $R f$ genes in the two progenies was controlled by two major additive-dominant epistatic genes and additive-dominant epistasis polygene. The two major genes had high additive effects and dominant effects. In addition, there existed significant epistatic effects between the two major genes. The major genes had high heritability in $\mathrm{F}_{2}, \mathrm{BC}_{1}$, and $\mathrm{BC}_{2}$ generations. Also, the fertility restorer characteristic can be selected during early generations of the breeding cycle.
\end{abstract}

Pepper is one of the most popular spice and vegetable crops in the world (Bosland and Votava, 2012). In their native habitats, peppers are grown as tender perennials, but in most parts of the world, they are grown as annuals. As with other crops, hybrid vigor can improve the yield, resistance, and quality of pepper. Cytoplasmic male sterility facilitates the production of hybrid seed. A major concern of hybrid seed production is prevention of self-pollination that can produce seeds that are not hybrid, and CMS greatly facilitates the production of $F_{1}$ hybrid seeds without the need for flower emasculation (Chase, 2007; Hanson and Bentolila, 2004). The pepper CMS system was first reported by Peterson in 1958 from an Indian Capsicum annuum accession (PI164835). Since then, CMS and associated restorer-of-fertility genes have been used

Received for publication 10 June 2019. Accepted for publication 3 Sept. 2019. Published online 18 November 2019.

This research was funded by the National Natural Sciences Foundation of China (31560555, 31760572) and by the Agricultural Science and Technology Foundation of the Gansu Academy of Agricultural Sciences (2016GAAS28). We thank Franchesca Ortega from the chile pepper breeding and genetics program and New Mexico State University for editing the manuscript. B.W. is the corresponding author. E-mail: bqwei@gsau.edu.cn.

This is an open access article distributed under the CC BY-NC-ND license (https://creativecommons.org/licenses/by-nc-nd/4.0/). to produce $F_{1}$ hybrids or hybrid cultivars (Kumar et al., 2009; Swamy et al., 2017).

Within the CMS system, the sterility (S) phenotype is controlled by mitochondrial genes. Two candidate genes for $\mathrm{S}$ are the mitochondrial loci, orf456 and atp6-2, identified and studied by Kim et al. (2007) and Kim and Kim (2006). Furthermore, two CMS-specific sequence-characterized amplified region (SCAR) markers, the coxII and the atp6 SCARs, have been developed from the sequences flanking orf 456 and atp6-2, respectively (Kim and Kim, 2005). In addition, another molecular marker of S-cytoplam, $\mathrm{SCAR}_{130}$, was reported to be more reliable than previous markers (Ji et al., 2014).

The CMS phenotype can be restored by a nuclear $R f$ gene, which can suppress the expression of the sterility orf in the mitochondria (Janska et al., 1998). In pepper, orf456 expression was suppressed in lines containing a nuclear-encoded $R f$ gene (Kim et al., 2007). By taking advantage of $R f$, the CMS/Rf system has been used to produce $\mathrm{F}_{1}$ hybrid seeds. The ability of restorer lines to reestablish fertility is one of the crucial components in the production of pepper $F_{1}$ hybrids using the $\mathrm{CMS} / \mathrm{Rf}$ system, and only restorer lines with very high restorer function and specificity can be used in the CMS/Rf system.

Although previous studies support the idea that restorer-offertility are controlled by one major gene (Gulyas et al., 2006; 
Peterson, 1958), several cases suggest that the inheritance of restorer-of-fertility is more complex. It has also been suggested that restorer-of-fertility in sweet pepper is controlled by two complementary genes (Novak et al., 1971), but it is still unclear how many $R f$ genes are present in pepper that contribute to restorer-of-fertility. Moreover, by mapping quantitative trait loci (QTLs), Wang et al. (2004) identified one major QTL, which was mapped to chromosome P6 and accounted for $20 \%$ to $69 \%$ of the phenotypic variation, and four minor QTLs related to restorer-of-fertility in pepper. In addition, other studies have shown that CMS can be temporarily broken down with a day/night temperature cycle of $25 / 17{ }^{\circ} \mathrm{C}$, but a high temperature cycle of $35 / 22{ }^{\circ} \mathrm{C}$ leads to $100 \%$ sterility, indicating the presence of modifying genes that are affected by environmental factors such as temperature (Bückmann et al., 2014; Peterson, 1958; Shifriss, 1997). The genetic mechanism of restorer-of-fertility is still not clearly understood. Therefore, understanding the mechanism of inheritance for restorer-offertility will be beneficial for breeding restorer lines with higher expression ability.

An analysis of inheritance using the joint segregation analysis method provides a method to test for all genetic explanations. The joint segregation analysis method can analyze for the best genetic model, gene heritability, and gene effects that fit the data for the quantitative trait (Cao et al., 2013; Gai et al., 2007; Zhang et al., 2000a). As a useful and strongly recommended technique that can analyze the segregation of quantitative traits, the joint segregation analysis method provides beneficial information for breeding by assisting in the design of breeding approaches that improve quantitative trait loci and progeny and parent selection (Ullah et al., 2016). The joint segregation analysis method provides an analysis of multiple traits and has been used widely in inheritance studies on different traits in wheat [Triticum aestivum (Ullah et al., 2016)], soybean [Glycine max (Wang and Gai, 1997)], cotton [Gossypium hirsutum (Zhang et al., 2011)], cucumber [Cucumis sativus (Liang et al., 2015)], and pepper (Yao et al., 2013). In this study, two progenies, constructed from the hybridization of CMS line $8 \mathrm{~A}$ with restorer lines R1 and R2, analyzed the inheritance mechanisms of fertility restoration for CMS in pepper by the joint segregation analysis method. The aims of this study were to understand the inheritance model of fertility restoration in pepper and the gene effects and inheritance, which will assist in choosing a breeding strategy for CMS hybrid.

\section{Materials and Methods}

Plant material. The pepper CMS line $8 \mathrm{~A}$ and its maintainer line $8 \mathrm{~B}$ were a pair of near-isogenic lines and were derived from 10 generations backcrossing of a mutated sterile individual plant and wild type fertile plants from pepper accession 9108 (C. annuum). Accession 9108 is a short and horn-shaped pepper with high pungency. The restorer lines R1 and R2 were selected through the testcross screening between CMS line 8A and inbred lines 2009A22-2 (C. annuum), as well as 2011A39-2 (C. annuum) respectively, both of which were long and horn-shaped pepper with moderate pungency. All accessions came from pepper program of Gansu Academy of Agricultural Sciences, China.

As shown in Fig. 1, six populations of two progenies were constructed. It should be noted that the construction of the $\mathrm{BC}_{1}$ population, $8 \mathrm{~B}$ was used as the backcrossing male parent to $8 \mathrm{~A}$
(A)

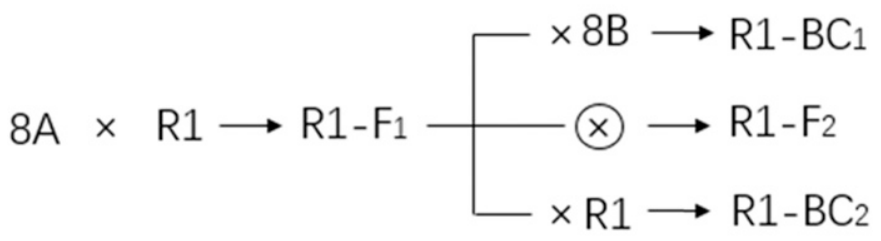

(B)

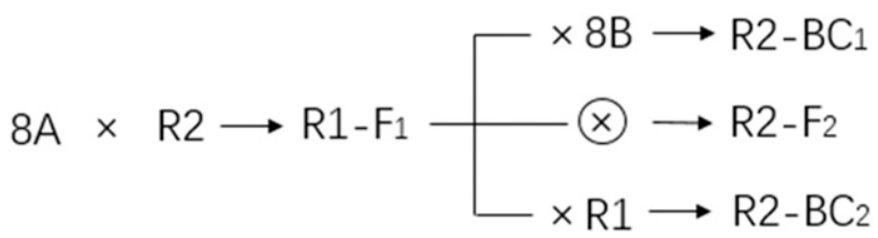

Fig. 1. The constructing flow sheet of populations for two pepper progenies. (A) $8 \mathrm{~A} \times \mathrm{R} 1$ progeny; $(\mathbf{B}) 8 \mathrm{~A} \times \mathrm{R} 2$ progeny. $8 \mathrm{~A}=$ a cytoplasmic male sterile line; $\mathrm{R} 1=$ one restorer-of-fertility line of $8 \mathrm{~A} ; \mathrm{R} 1-\mathrm{F}_{1}=$ cross of $8 \mathrm{~A}$ and $\mathrm{R} 1 ; 8 \mathrm{~B}=$ isogenic and maintainer line of $8 \mathrm{~A} ; \mathrm{R} 1-\mathrm{BC}_{1}=$ backcross of $\mathrm{R} 1-\mathrm{F}_{1}$ and $8 \mathrm{~B} ; \mathrm{R} 1-$ $\mathrm{BC}_{2}=$ backcross of $\mathrm{R} 1-\mathrm{F}_{1}$ and $\mathrm{R} 1 ; \mathrm{R} 1-\mathrm{F}_{2}=\mathrm{F}_{2}$ generation of $8 \mathrm{~A}$ and $\mathrm{R} 1 ; \mathrm{R} 2=$ another restorer-of-fertility line of $8 \mathrm{~A} ; \mathrm{R} 2-\mathrm{F}_{1}=\operatorname{cross}$ of $8 \mathrm{~A}$ and $\mathrm{R} 2 ; \mathrm{R} 2-\mathrm{BC}_{1}=$ backcross of R2- $\mathrm{F}_{1}$ and $8 \mathrm{~B} ; \mathrm{R} 2-\mathrm{BC}_{2}=$ backcross of $\mathrm{R} 2-\mathrm{F}_{1}$ and $\mathrm{R} 2 ; \mathrm{R} 2-\mathrm{F}_{2}=\mathrm{F}_{2}$ generation of $8 \mathrm{~A}$ and $\mathrm{R} 2$.

Table 1. Number of plants in populations of pepper used for inheritance analysis.

\begin{tabular}{|c|c|c|c|}
\hline Generation $^{z}$ & Plants (no.) & Generation $^{y}$ & Plants (no.) \\
\hline $8 \mathrm{~A}$ & 30 & $8 \mathrm{~A}$ & 30 \\
\hline R1 & 30 & $\mathrm{R} 2$ & 30 \\
\hline $\mathrm{R} 1-\mathrm{F}_{1}(8 \mathrm{~A} \times \mathrm{R} 1)$ & 40 & $\mathrm{R} 2-\mathrm{F}_{1}(8 \mathrm{~A} \times \mathrm{R} 2)$ & 40 \\
\hline $\mathrm{R} 1-\mathrm{BC}_{1}\left(\mathrm{R} 1-\mathrm{F}_{1} \times 8 \mathrm{~B}\right)$ & 76 & $\mathrm{R} 2-\mathrm{BC}_{1}\left(\mathrm{R} 2-\mathrm{F}_{1} \times 8 \mathrm{~B}\right)$ & 79 \\
\hline $\mathrm{R} 1-\mathrm{BC}_{2}\left(\mathrm{R} 1-\mathrm{F}_{1} \times \mathrm{R} 1\right)$ & 77 & $\mathrm{R} 2-\mathrm{BC}_{2}\left(\mathrm{R} 2-\mathrm{F}_{1} \times \mathrm{R} 2\right)$ & 53 \\
\hline $\mathrm{R} 1-\mathrm{F}_{2}\left(\mathrm{R} 1-\mathrm{F}_{1}\right.$ selfed $)$ & 321 & $\mathrm{R} 2-\mathrm{F}_{2}\left(\mathrm{R} 2-\mathrm{F}_{1}\right.$ selfed $)$ & 267 \\
\hline
\end{tabular}

$\overline{\mathrm{z}} 8 \mathrm{~A}=$ a cytoplasmic male sterile line; $\mathrm{R} 1=$ one restorer-of-fertility line of $8 \mathrm{~A} ; \mathrm{R} 1-\mathrm{F}_{1}=$ cross of $8 \mathrm{~A}$ and $\mathrm{R} 1 ; 8 \mathrm{~B}=$ isogenic and maintainer line of $8 \mathrm{~A} ; \mathrm{R} 1-\mathrm{BC}_{1}=$ backcross of $\mathrm{R} 1-\mathrm{F}_{1}$ and $8 \mathrm{~B} ; \mathrm{R} 1-\mathrm{BC}_{2}=$ backcross of $\mathrm{R} 1-\mathrm{F}_{1}$ and $\mathrm{R} 1 ; \mathrm{R} 1-\mathrm{F}_{2}=\mathrm{F}_{2}$ generation of $8 \mathrm{~A}$ and $\mathrm{R} 1$.

${ }^{\mathrm{y}} 8 \mathrm{~A}=$ a cytoplasmic male sterile line; $\mathrm{R} 2=$ another restorer-of-fertility line of $8 \mathrm{~A} ; \mathrm{R} 2-\mathrm{F}_{1}=$ cross of $8 \mathrm{~A}$ and $\mathrm{R} 2 ; 8 \mathrm{~B}=$ isogenic and maintainer line of $8 \mathrm{~A} ; \mathrm{R} 2-\mathrm{BC}_{1}=$ backcross of $\mathrm{R} 2-\mathrm{F}_{1}$ and $8 \mathrm{~B} ; \mathrm{R}_{2}-\mathrm{BC}_{2}=$ backcross of $\mathrm{R} 2-\mathrm{F}_{1}$ and $\mathrm{R} 2 ; \mathrm{R} 2-\mathrm{F}_{2}=\mathrm{F}_{2}$ generation of $8 \mathrm{~A}$ and $\mathrm{R} 2$.

because of lack of pollen in $8 \mathrm{~A}$. The first set of progeny included six populations: $8 \mathrm{~A}, \mathrm{R} 1, \mathrm{R} 1-\mathrm{F}_{1}, \mathrm{R} 1-\mathrm{F}_{2}, \mathrm{R} 1-\mathrm{BC}_{1}$, and $\mathrm{R} 1-\mathrm{BC}_{2}$. The second set of progeny included six populations: $8 \mathrm{~A}, \mathrm{R} 2, \mathrm{R} 2-\mathrm{F}_{1}, \mathrm{R} 2-\mathrm{F}_{2}, \mathrm{R} 2-\mathrm{BC}_{1}$, and R1-BC 2 . The number for each population is shown in Table 1 .

All populations were planted in a plastic tunnel greenhouse from the beginning of April to the end of August 2015. The plants where spaced $30 \times 40 \mathrm{~cm}$ apart. Before planting, $\approx 15,000 \mathrm{~kg} \cdot \mathrm{ha}^{-1}$ farm manure and $600 \mathrm{~kg} \cdot \mathrm{ha}^{-1}$ urea were plowed into the soil. When flowering began, an additional $150 \mathrm{~kg} \cdot \mathrm{ha}^{-1}$ urea were added through the irrigation every $20 \mathrm{~d}$. An insect-proof net covered the plants throughout the growing period, and pesticide was used periodically to prevent pollination by insects.

Determination of FERTILITY. A fertility rating (FR) of five flowers per plant was scored during anthesis, with a score of $0=$ no visible pollen on the anther, $1=$ only a few pollen grains, $2=$ 
Table 2. Different genetic models tested on the pepper progeny produced for this investigation and their implications.

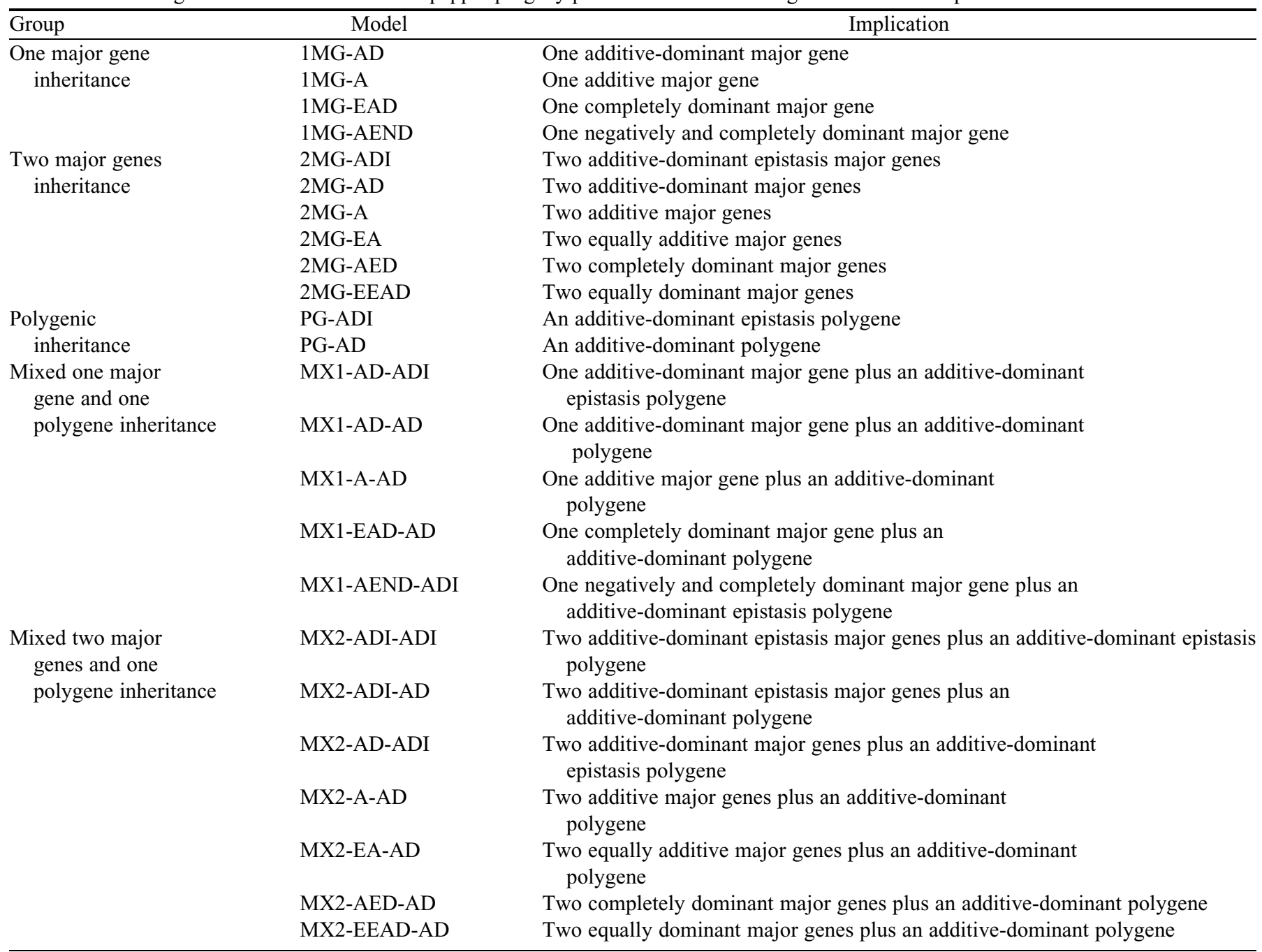

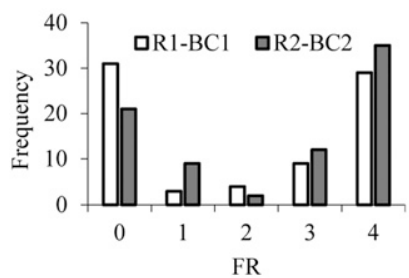

(A)

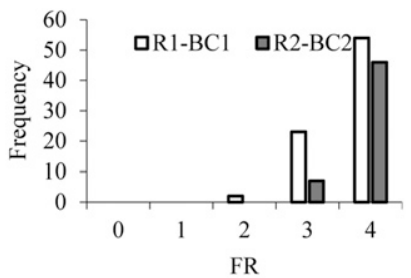

(B)

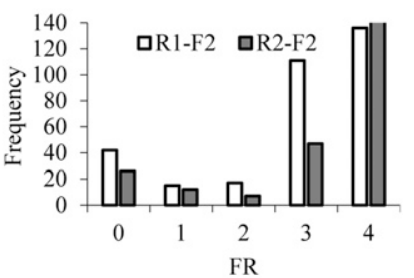

(C)

Fig. 2. The frequency distribution for different index of fertility in different populations of two pepper progenies. (A) $\mathrm{BC}_{1} ;$ (B) $\mathrm{BC}_{2} ;$ (C) $\mathrm{F}_{2}$. R1-BC 1 = backcross of $\mathrm{R} 1-\mathrm{F}_{1}$ and $8 \mathrm{~B}$; R1-BC $=$ backcross of $\mathrm{R} 1-\mathrm{F}_{1}$ and $\mathrm{R} 1 ; \mathrm{R} 1-\mathrm{F}_{2}=$ $\mathrm{F} 2$ generation of $8 \mathrm{~A}$ and $\mathrm{R} 1$; $\mathrm{R} 2-\mathrm{BC}_{1}=$ backcross of $\mathrm{R} 2-\mathrm{F}_{1}$ and $8 \mathrm{~B}$; $\mathrm{R} 2-\mathrm{BC}_{2}=$ backcross of $\mathrm{R} 2-\mathrm{F}_{1}$ and $\mathrm{R} 2$; R2$\mathrm{F}_{2}=\mathrm{F}_{2}$ generation of $8 \mathrm{~A}$ and $\mathrm{R} 2$.

many pollen grains on less than $50 \%$ of the anther exterior, $3=$ many pollen grains on up to $50 \%$ of the anther exterior, and $4=$ many pollen grains covering up to $80 \%$ of the anther exterior (Wang et al., 2004). The FR of a plant was equal to the average of the five flowers.

INHERITANCE ANALYSIS. For inheritance analysis, six generations were analyzed by the joint segregation analysis method (Gai and Wang, 1998; Wang, 1996; Zhang et al., 2000a). The analysis was based on the mixed one major gene plus polygene of component distributions in different models were derived from the data of the six generations through the iterated expectation and conditional maximization (IECM) algorithm (Gai et al., 2003). Then, the Akaike's information criterion (AIC) values were calculated from the MLV (Akaike, 1997). According to the entropy maximum principle, (AIC minimum principle) was the optimal assumption (Akaike, 1997), the models with lowest AIC values can be chosen as candidates. Next, the $U_{1}{ }^{2}, U_{2}{ }^{2}$, and $U_{3}{ }^{2}$ uniformity test; ${ }_{n} W^{2}$ Smirnov test; and $D_{n}$ Kolmogorov test were used for 
Table 3. Maximum likelihood value (MLV) and Akaike's information criterion (AIC) value of candidate genetic models in $8 \mathrm{~A} \times \mathrm{R} 1$ pepper progeny.

\begin{tabular}{llll}
\hline Progeny $^{\mathrm{z}}$ & \multicolumn{1}{c}{ Model $^{\mathrm{y}}$} & \multicolumn{1}{c}{ MLV } & AIC value \\
\hline 8A $\times \mathrm{R} 1$ & 2MG-ADI & -378.674 & 777.3484 \\
& MX2-ADI-ADI & -391.225 & 818.449 \\
& MX2-ADI-AD & -379.99 & 789.9798
\end{tabular}

${ }^{\mathrm{z}} 8 \mathrm{~A} \times \mathrm{R} 1=$ progeny of the parents and the cross of $8 \mathrm{~A}$ and $\mathrm{R} 1$.

${ }^{\mathrm{y}} 2 \mathrm{MG}-\mathrm{ADI}=$ two additive-dominant epistasis major genes; MX2ADI-ADI $=$ two additive-dominant epistasis major genes plus an additive-dominant epistasis polygene; MX2-ADI-AD = two additivedominant epistasis major genes plus an additive-dominant polygene.

the goodness-of-fit to check whether the candidate models could sufficiently explain the data. The candidate model with the largest number of no significant difference statistics was considered the best-fitting model. In other words, the model with the least number of significant difference statistics was most suitable. Finally, the genetic parameters were obtained from the parameters of component distributions in the most suitable model. The AIC value and other corresponding parameters were calculated using the SEA software program (Cao et al., 2013).

\section{Results}

VARIATION OF FERTILITY AMONG THE SIX POPUlATIONS. Two progenies show similar pollen variance. The parent $8 \mathrm{~A}$ had complete sterility with no pollen on slight anthers, whereas the R1 and R2 parents had full fertility with copious amounts of pollen on swollen anthers, and the $\mathrm{R} 1-\mathrm{F}_{1}$ and $\mathrm{R} 2-\mathrm{F}_{1}$ populations had sphenotype similar to the male parent. The R1-BC 1 and R2$\mathrm{BC}_{1}$ segregated for both fertile and sterile flowers, whereas the $\mathrm{R} 1-\mathrm{BC}_{2}$ and $\mathrm{R} 2-\mathrm{BC}_{2}$ segregated with a tendency toward the fertile end, and the $\mathrm{R} 1-\mathrm{F}_{2}$ and $\mathrm{R} 2-\mathrm{F}_{2}$ population segregated for both fertile and sterile flowers with more fertile flowers (Fig. 2).

INHERITANCE ANALYSIS. In the $8 \mathrm{~A} \times \mathrm{R} 1$ progenies, the model 2MG-ADI had the smallest AIC value of 777.3, followed by MX2-ADI-AD (790.0) and MX2-ADI-ADI (818.5) (Table 3). According to the AIC minimum principle, the models with the lowest AIC values should be chosen as the candidate models. Therefore, 2MG-ADI, MX2-ADI-ADI, and MX2-ADI-AD were the best candidate models to explain the restorer-offertility in $8 \mathrm{~A} \times \mathrm{R} 1$ progenies. Subsequently, a set of goodnessof-fit tests was conducted among the three candidate models to understand which candidate model could sufficiently explain the data. According to the goodness-of-fit principle, the model with the least number is the most suitable model. There were 14 significant difference statistics in model MX2-ADI-ADI, whereas there were 15 and 16 significant difference statistics in model 2MG-ADI and model MX2-ADI-AD, respectively (Table 4). Thus, MX2-ADI-ADI was the best-fitting genetic model to explain the inheritance of restorer-of-fertility in $8 \mathrm{~A} \times \mathrm{R} 1$. This model specified that the restorer-of-fertility is controlled by two major additive-dominant epistasis genes and an additive-dominant epistasis polygene in the $8 \mathrm{~A} \times \mathrm{R} 1$ progenies.

In $8 \mathrm{~A} \times \mathrm{R} 2$ progenies, the model $2 \mathrm{MG}-\mathrm{ADI}$ had the smallest AIC value of 534.9, followed by MX2-AD-AD (603.8), MX2A-AD (646.3), MX2-ADI-ADI (679.5), and MX2-ADI-AD (680.7) (Table 5). Therefore, 2MG-ADI, MX2-AD-AD, MX2-
A-AD, MX2-ADI-ADI, and MX2-ADI-AD were chosen as the best candidates for explaining the restorer-of-fertility in $8 \mathrm{~A} \times \mathrm{R} 2$ progenies according to the AIC minimum principle. Subsequently, a set of goodness-of-fit test was also conducted as in $8 \mathrm{~A} \times \mathrm{R} 2$ progenies. Interestingly, there were 15 significant difference statistics in model MX2-ADI-ADI, whereas there were more than 16 in other models. Thus, the MX2-ADI-ADI was the best-fitting genetic model to explain the inheritance of restorer-of-fertility in $8 \mathrm{~A} \times \mathrm{R} 2$ progenies (Table 6 ). This meant that the restorer-of-fertility is controlled by two major additive-dominant epistasis genes and additive-dominant epistasis polygene in $8 \mathrm{~A} \times \mathrm{R} 2$ progenies. Thus, it can be concluded that the restorer-of-fertility is controlled by two major additive-dominant epistasis genes and additivedominant epistasis polygene in both $8 \mathrm{~A} \times \mathrm{R} 1$ progenies and $8 \mathrm{~A} \times \mathrm{R} 2$ progenies.

ESTIMATION OF GENETIC PARAMETERS IN 8A $\times$ R1 PROGENIES. In $8 \mathrm{~A} \times \mathrm{R} 1$ progenies, the parameters of component distributions of the best-fitting model MX2-ADI-ADI were derived through the IECM algorithm (Table 7). The first- and second-order genetic parameters of the best-fitting model MX2-ADI-ADI were then calculated from its parameters of component distributions (Table 8). The additive effect of two major genes was equal to -0.954 . The dominant effect of the first major gene was greater than that of the second major gene. The dominant value of the first major gene was 1.249, and the second major gene had a very low dominant effect with a value of -0.045 . The first major gene took on overdominance with a dominant degree of 1.31 , whereas the dominant degree of the second major gene was only 0.05 . The first major gene mainly acted with both additive and dominant effects, whereas the second major gene only had an additive effect.

There were also epistatic effects between the two major genes. The largest epistatic interaction was the additive effect of the second major gene $\times$ the dominant effect of the first major gene $\left(j_{b a}\right)$, supported by a value of 1.3575 . The second largest epistatic effect was of the dominant effect of the first major gene $\times$ the dominant effect of the second major gene $(l)$ with a value of 0.4752 . The third epistatic effect between the additive effect of the first gene $\times$ additive effect of the second gene $(i)$ was -0.212 . The fourth epistatic effect between the additive effect of the first major gene $\times$ dominant effect of the second major gene $\left(j_{a b}\right)$ was only -0.052 . These indicated that the fertility restorer of CMS was largely affected by epistasis, especially the epistatic interaction of the additive effect of the second major gene $\times$ dominant effect of the first major gene $\left(j_{b a}\right)$.

With regard to the genetic variance of $\mathrm{R} 1-\mathrm{BC}_{1}, \mathrm{R}_{1}-\mathrm{BC}_{2}$, and $\mathrm{R} 1-\mathrm{F}_{2}$, respectively, the phenotypic variances were 3.1742, 0.2107 and 1.7078; the major genes' variance were 3.0407, 0.1525 , and 1.6744 ; the polygene's variance were 0.1206 , 0.0453 , and 0.0205; and the environmental variance of all were 0.0129 . The heritability of $\mathrm{R} 1-\mathrm{BC}_{1}, \mathrm{R} 1-\mathrm{BC}_{2}$, and $\mathrm{R} 1-\mathrm{F}_{2}$ were calculated from the genetic variance. The genotype had high heritability with values of $0.9959,0.9388$, and 0.9925 in R1$\mathrm{BC}_{1}, \mathrm{R} 1-\mathrm{BC}_{2}$, and $\mathrm{R} 1-\mathrm{F}_{2}$ generations, respectively. This suggested that a major gene contributed to the main role with the heritability values of $0.9579,0.7236$, and 0.9805 , and the polygene heritability were $0.038,0.2152$, and 0.012 . The environmental effect was relatively low with values of $0.0041,0.0612$, and 0.0075 , respectively. This indicates that the heritability was mainly controlled by genotype, especially 
Table 4. Tests for goodness-of-fit of candidate models of fertility restorer in $8 \mathrm{~A} \times \mathrm{R} 1$ progenies of pepper.

\begin{tabular}{|c|c|c|c|c|c|c|}
\hline \multirow[b]{2}{*}{ Model $^{\mathrm{z}}$} & \multirow[b]{2}{*}{ Population ${ }^{y}$} & \multicolumn{5}{|c|}{ Maximum likelihood estimates of component distribution parameters ${ }^{\mathrm{x}}$} \\
\hline & & $U_{1}^{2}$ & $U_{2}^{2}$ & $U_{3}^{2}$ & ${ }_{n} W^{2}$ & $D_{n}$ \\
\hline \multirow[t]{5}{*}{ 2MG-ADI } & $8 \mathrm{~A}$ & $45.34(0)^{* *}$ & $24.54(0)^{* *}$ & $39.25(0)^{* *}$ & $5.75(0)^{* *}$ & $0.03(1)$ \\
\hline & $\mathrm{R} 1-\mathrm{F}_{1}$ & $5.88(0.02)^{*}$ & $2.57(0.11)$ & $8.86(0)^{* *}$ & $2.98(0) * *$ & $0.33(0)^{* *}$ \\
\hline & $\mathrm{R} 1-\mathrm{BC}_{1}$ & $0.10(0.75)$ & $0.12(0.72)$ & $0.03(0.87)$ & $0.40(0.08)$ & $0.13(0.14)$ \\
\hline & $\mathrm{R} 1-\mathrm{BC}_{2}$ & $0.04(0.85)$ & $0.04(0.84)$ & $2.40(0.12)$ & $0.74(0.02)^{*}$ & $0.22(0)^{* *}$ \\
\hline & $\mathrm{R} 1-\mathrm{F}_{2}$ & $0(0.95)$ & $0(0.98)$ & $0.02(0.89)$ & $0.92(0) * *$ & $0.13(0)^{* *}$ \\
\hline & $\mathrm{R} 1-\mathrm{F}_{1}$ & $1.76(0.19)$ & $0.06(0.80)$ & $16.99(0)^{* *}$ & $2.60(0)^{* *}$ & $0.38(0)^{* *}$ \\
\hline & $\mathrm{R} 1$ & $1.31(0.25)$ & $0.04(0.84)$ & $13.08(0)^{* *}$ & $1.95(0)^{* *}$ & $0.38(0)^{* *}$ \\
\hline & $\mathrm{R} 1-\mathrm{BC}_{1}$ & $0(0.98)$ & $0.07(0.78)$ & $1.39(0.24)$ & $0.44(0.06)$ & $0.16(0.03)^{*}$ \\
\hline & $\mathrm{R} 1-\mathrm{BC}_{2}$ & $0.29(0.59)$ & $0.08(0.78)$ & $0.95(0.33)$ & $0.71(0.02)^{*}$ & $0.21(0)^{* *}$ \\
\hline & $\mathrm{R} 1-\mathrm{F}_{2}$ & $0.08(0.78)$ & $0.19(0.66)$ & $0.42(0.52)$ & $0.94(0) * *$ & $0.12(0)^{* *}$ \\
\hline \multirow[t]{2}{*}{ MX2-ADI-AD } & $8 \mathrm{~A}$ & $5.55(0.02)^{*}$ & $8.47(0)^{* *}$ & $6.32(0.02)^{*}$ & $2.32(0) * *$ & 0.03 (1) \\
\hline & $\mathrm{R} 1-\mathrm{F}_{2}$ & $0(0.96)$ & $0(1)$ & $0.05(0.83)$ & $0.91(0)^{* *}$ & $0.13(0)^{* *}$ \\
\hline
\end{tabular}

$\overline{\mathrm{z}} 2 \mathrm{MG}-\mathrm{ADI}=$ two additive-dominant epistasis major genes; MX2-ADI-ADI = two additive-dominant epistasis major genes plus an additivedominant epistasis polygene; MX2-ADI-AD = two additive-dominant epistasis major genes plus an additive-dominant polygene.

${ }^{\mathrm{y}} 8 \mathrm{~A}=$ a cytoplasmic male sterile line; $\mathrm{R} 1=$ one restorer-of-fertility line of $8 \mathrm{~A} ; \mathrm{R} 1-\mathrm{F}_{1}=$ cross of $8 \mathrm{~A}$ and $\mathrm{R} 1 ; 8 \mathrm{~B}=$ isogenic and maintainer line of $8 \mathrm{~A} ; \mathrm{R} 1-\mathrm{BC}_{1}=$ backcross of $\mathrm{R} 1-\mathrm{F}_{1}$ and $8 \mathrm{~B} ; \mathrm{R} 1-\mathrm{BC}_{2}=$ backcross of $\mathrm{R} 1-\mathrm{F}_{1}$ and $\mathrm{R} 1 ; \mathrm{R} 1-\mathrm{F}_{2}=\mathrm{F}_{2}$ generation of $8 \mathrm{~A}$ and $\mathrm{R} 1$.

${ }^{\mathrm{x}} U_{1}^{2}, U_{2}^{2}$, and $U_{3}^{2}$ are the uniformity test statistics; ${ }_{n} W^{2}$ is the Smirnov test statistic; and $D_{n}$ is the Kolmogorov test statistic.

*, ** Significant at $P \leq 0.05$ or 0.01 , respectively.

Table 5. Maximum likelihood value (MLV) and Akaike's information criterion (AIC) value of candidate genetic models in $8 \mathrm{~A} \times \mathrm{R} 2$ pepper progeny.

\begin{tabular}{lllc}
\hline Progeny $^{\mathrm{z}}$ & \multicolumn{1}{c}{ Model $^{\mathrm{y}}$} & \multicolumn{1}{c}{ MLV } & AIC value \\
\hline 8A $\times \mathrm{R} 2$ & 2MG-ADI & -257.427 & 534.85 \\
& MX2-ADI-ADI & -521.75 & 679.49 \\
& MX2-ADI-AD & -325.33 & 680.66 \\
& MX2-AD-AD & -290.92 & 603.83 \\
& MX2-A-AD & -414.16 & 646.32
\end{tabular}

${ }^{\mathrm{z}} 8 \mathrm{~A} \times \mathrm{R} 2=$ progeny of the parents and the cross of $8 \mathrm{~A}$ and $\mathrm{R} 2$.

${ }^{\mathrm{y}} 2 \mathrm{MG}-\mathrm{ADI}=$ two additive-dominant epistasis major genes; MX2ADI-ADI $=$ two additive-dominant epistasis major genes plus an additive-dominant epistasis polygene; MX2-ADI-AD = two additivedominant epistasis major genes plus an additive-dominant polygene; $\mathrm{MX} 2-\mathrm{AD}-\mathrm{AD}=$ two additive-dominant major genes plus an additivedominant polygene; MX2-A-AD = two additive major genes plus an additive-dominant polygene.

major genes. This also suggests that the fertility characteristic could be selected during earlier generations.

ESTIMATION OF GENETIC PARAMETERS IN 8A $\times \mathbf{R} 2$ PROGENIES. In $8 \mathrm{~A} \times \mathrm{R} 2$ progenies, the parameters of component distributions of the best-fitting model MX2-ADI-ADI were also derived through IECM algorithm (Table 9). The first- and second-order genetic parameters of model MX2-ADI-ADI were then calculated from its parameters of component distributions (Table 10). The additive effect of two major genes was also equal to a value of -0.8734 . The dominant effect of the first major gene was greater than that of the second major gene. The dominant value of the first major gene was 0.8959 and of the second major gene was 0.3512 ; the proportion of the first and second major genes was 2.55. The first major gene showed complete dominance, with a dominant degree of 1.03, whereas the second major gene exhibited partial dominance with a dominant degree of 0.40 .

An epistatic effect was observed between the two major genes. The greatest epistatic effect was the additive effect of the second major gene $\times$ dominant effect of the first major gene $\left(j_{b a}\right)$ with a value of 0.896 . The second greatest epistatic effect was the additive effects between the two major genes $(i)$ with a value of -0.8731 . The last two epistatic effects were close in value, with the additive effect of the first major gene $\times$ dominant effect of the second major gene $\left(j_{a b}\right)$ and the dominant effects between two major genes $(l)$ having values of 0.3513 and -0.3431 , respectively. This added evidence supports the idea that restorer-to-fertility for CMS was largely affected by the epistasis, especially the additive effect of the second major gene $\times$ dominant effect of the first major gene $\left(j_{b a}\right)$ and the additive effects between the two major genes $(i)$.

With regard to the genetic variance of $\mathrm{R} 2-\mathrm{BC}_{1}, \mathrm{R} 2-\mathrm{BC}_{2}$, and $\mathrm{R} 2-\mathrm{F}_{2}$, the phenotypic variances were $2.9086,0.2107$, and 1.5629 , and the major genes' variances were 2.7954, 0.0029, and 1.4679 . The polygenes variances were $0.1003,0.1949$, and 0.0821 , with the environmental variance for all was 0.0129 . The heritability of $\mathrm{R} 2-\mathrm{BC}_{1}, \mathrm{R} 2-\mathrm{BC}_{2}$, and $\mathrm{R} 2-\mathrm{F}_{2}$ was calculated from the genetic variance. The genotype represented the highest heritability with values of $0.9956,0.9388$, and 0.9917 in R2$\mathrm{BC}_{1}, \mathrm{R} 2-\mathrm{BC}_{2}$, and R2-F 2 generations. In the R2-BC 1 and R2-F generations, major genes contributed to the main effect with the heritability values of 0.9611 and 0.9392 , and the polygene heritability was 0.0345 and 0.0525 . In $\mathrm{R} 2-\mathrm{BC}_{2}$ generations, polygenes contributed to the main effect with a heritability value of 0.925 , and the major gene heritability was only 0.0138 . The environmental effects were relatively lower, with values of $0.0044,0.0612$, and 0.0083 . These values indicate that the heritability was mainly controlled by the genotype, especially 


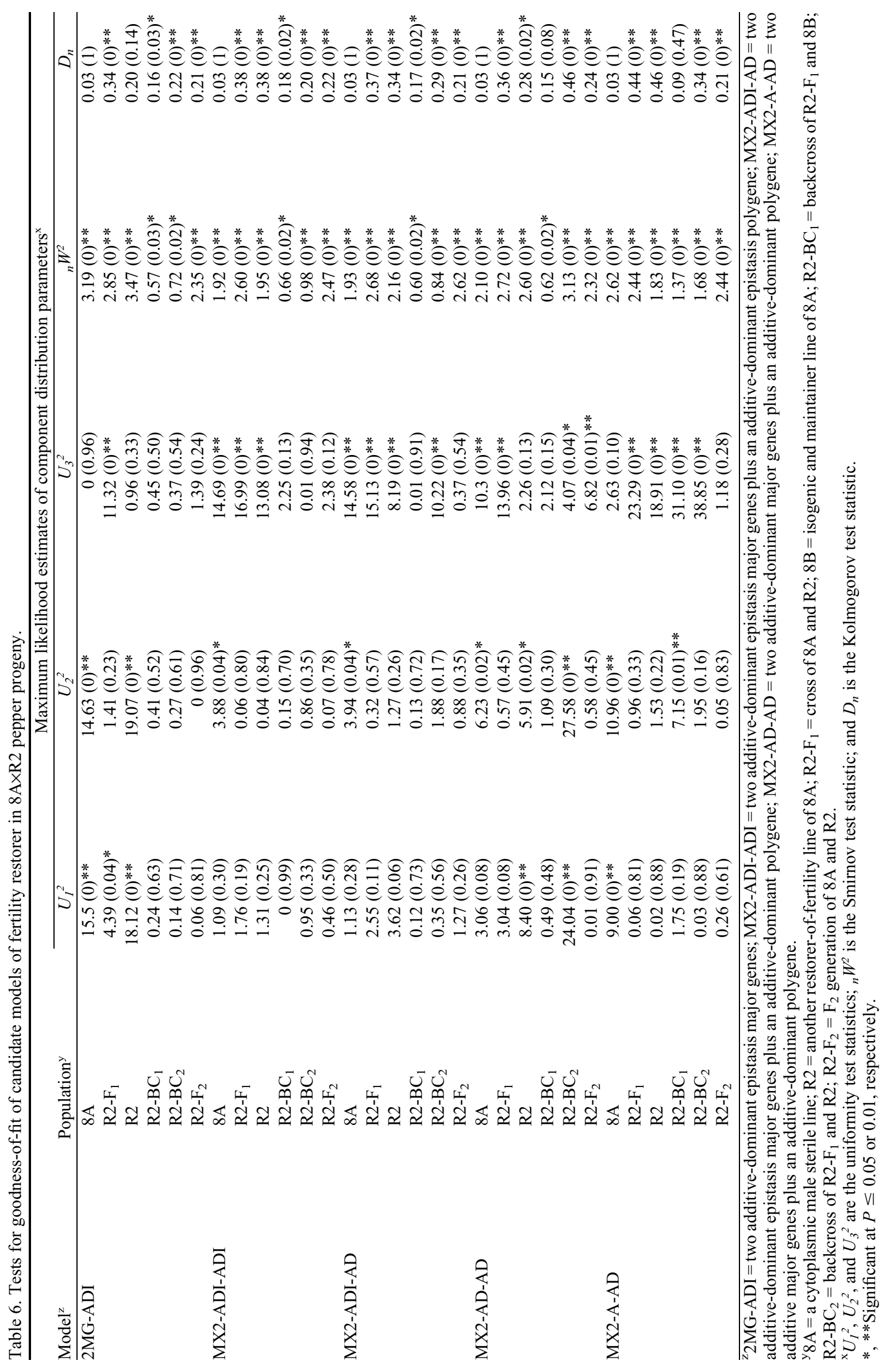


Table 7. Maximum likelihood estimation of component distribution and polygenetic variance parameters of $8 \mathrm{~A} \times \mathrm{R} 1$ pepper progeny. Parameter $^{\mathrm{z}}$ Estimation Parameter ${ }^{\mathrm{z}}$ Estimation Parameter ${ }^{\mathrm{z}}$ Estimation

$\begin{array}{llllll}\mu_{1} & 0.0167 & \mu_{52} & 3.0377 & \mu_{66} & 3.0613\end{array}$

$\begin{array}{llllll}\mu_{2} & 3.95 & \mu_{53} & 3.1535 & \mu_{67} & 2.4273\end{array}$

$\mu_{3} \quad 3.98$

$\mu_{41} \quad 0.049$

$\mu_{42} \quad 1.1182$

$\mu_{43} \quad 3.8214$

$\mu_{44} \quad 3.8496$

$\mu_{54} \quad 3.8888$

$\mu_{61} \quad 0.0956$

$\mu_{62} \quad 1.1648$

$\begin{array}{ll}\mu_{62} & 2.4273\end{array}$

3.8716

$\mu_{64}$

3.868

3.8952

$\mu_{68}$

3.177

$\mu_{69} \quad 3.9124$

$\delta^{2}$

0.0129

$\delta^{2}{ }_{40}$

0.1335

$\mu_{51}$

$\mu_{65}$

$\delta^{2}{ }_{50}$

0.0582

${ }^{\mathrm{z}} \mu_{1}, \mu_{2}$, and $\mu_{3}=$ component distribution of $8 \mathrm{~A}, \mathrm{R} 1-\mathrm{F}_{1}$, and $\mathrm{R} 1 ; \mu_{41^{-}}$ $\mu_{44}=$ component distribution of $\mathrm{R} 1-\mathrm{BC}_{1} ; \mu_{51}-\mu_{54}=$ component distribution of $\mathrm{R} 1-\mathrm{BC}_{2} ; \mu_{61}-\mu_{69}=$ component distribution of $\mathrm{R} 1-\mathrm{F}_{2}$; $\delta^{2}=$ error variance; $\delta_{40}^{2}, \delta^{2}{ }_{50}$, and $\delta^{2}{ }_{60}=$ polygenetic variance of components distribution of $\mathrm{R} 1-\mathrm{BC}_{1}, \mathrm{R} 1-\mathrm{BC}_{2}$, and $\mathrm{R} 1-\mathrm{F}_{2}$.

Table 8. Estimates of genetic parameters in model MX2-ADI-ADI for fertility restorer of $8 \mathrm{~A} \times \mathrm{R} 1$ pepper progeny.

\begin{tabular}{|c|c|c|c|c|c|}
\hline \multirow{2}{*}{$\begin{array}{l}\text { First-order } \\
\text { parameter }^{z} \\
\end{array}$} & \multirow[b]{2}{*}{ Estimate } & \multirow{2}{*}{$\begin{array}{l}\text { Second-order } \\
\text { parameter }^{\mathrm{y}}\end{array}$} & \multicolumn{3}{|c|}{ Estimation in generation $^{\mathrm{x}}$} \\
\hline & & & $\mathrm{R} 1-\mathrm{BC}_{1}$ & $\mathrm{R} 1-\mathrm{BC}_{2}$ & $\mathrm{R} 1-\mathrm{F}_{2}$ \\
\hline$\overline{m_{1}}$ & 2.1367 & $\overline{\delta_{p}^{2}}$ & 3.1742 & 0.2107 & 1.7078 \\
\hline$m_{2}$ & 2.2705 & $\delta^{2}{ }_{m g}$ & 3.0407 & 0.1525 & 1.6744 \\
\hline$m_{3}$ & 2.2832 & $\delta_{p g}^{2}$ & 0.1206 & 0.0453 & 0.0205 \\
\hline$m_{4}$ & 2.1691 & $\delta^{2}{ }_{e}$ & 0.0129 & 0.0129 & 0.0129 \\
\hline$m_{5}$ & 2.1921 & $h^{2}{ }_{m g}$ & 0.9579 & 0.7236 & 0.9805 \\
\hline$m_{6}$ & 2.2156 & $h_{p g}^{2}$ & 0.038 & 0.2152 & 0.012 \\
\hline$d_{a}$ & -0.954 & $h^{2}{ }_{m g+p g}$ & 0.9959 & 0.9388 & 0.9925 \\
\hline$d_{b}$ & -0.954 & $1-h_{m g+p g}^{2}$ & 0.0041 & 0.0612 & 0.0075 \\
\hline$h_{a}$ & 1.249 & & & & \\
\hline$h_{b}$ & -0.045 & & & & \\
\hline$\left|h_{a}\right| /\left|d_{a}\right|$ & 1.3092 & & & & \\
\hline$\left|h_{b}\right| /\left|d_{b}\right|$ & 0.0472 & & & & \\
\hline$i$ & -0.212 & & & & \\
\hline$j_{a b}$ & -0.052 & & & & \\
\hline$j_{b a}$ & 1.3575 & & & & \\
\hline$l$ & 0.4752 & & & & \\
\hline
\end{tabular}

${ }_{m_{1}-m_{6}}=$ mean of graduation; $d_{a}=$ additive effects of the first major gene; $d_{b}=$ additive effects of the second major gene; $h_{a}=$ dominant effects of the first major gene; $h_{b}=$ dominant effects of the second major gene; $\left|h_{a}\right| / d_{a} \mid=$ dominant degree of the first gene; $\left|h_{b}\right| / d_{b} \mid=$ dominant degree of the second major gene; $i=$ epistemic effect of additive $\times$ additive between two major gene; $j_{a b}=$ epistatic effect of additive of the first major gene $\times$ dominant of the second major gene; $j_{b a}=$ epistatic effect of additive of the second major gene $\times$ dominant of the first major gene; $l=$ epistemic effect of dominate $\times$ dominant between two major gene.

${ }^{\mathrm{y}} \delta^{2}{ }_{p}=$ phenotypic variance; $\delta^{2}{ }_{m g}=$ main gene variance; $\delta_{p g}^{2}=$ polygene variance; $\delta^{2}{ }_{e}=$ error variance; $h^{2}{ }_{m g}=$ major gene heritability; $h_{p g}^{2}=$ polygene heritability; $h^{2}{ }_{m g+p g}=$ gene heritability; $1-h^{2}{ }_{m g+p g}=$ environmental efficiency.

${ }^{\mathrm{x}} \mathrm{R} 1-\mathrm{BC} \mathrm{C}_{1}=$ backcross of $\mathrm{R} 1-\mathrm{F}_{1}$ and $8 \mathrm{~B} ; \mathrm{R} 1-\mathrm{BC}_{2}=$ backcross of $\mathrm{R} 1-\mathrm{F}_{1}$ and $\mathrm{R} 1 ; \mathrm{R} 1-\mathrm{F}_{2}=\mathrm{F}_{2}$ generation of $8 \mathrm{~A}$ and $\mathrm{R} 1$.

major genes. This again suggests that the fertility characteristic can be selected during earlier generations of the breeding cycle.

\section{Discussion}

The CMS/Rf system is one of the best approaches for heterosis utilization. However, CMS in pepper is not often
Table 9. Maximum likelihood estimation of component distribution and polygenetic variance parameters of $8 \mathrm{~A} \times \mathrm{R} 2$ pepper progeny.

\begin{tabular}{llllll}
\hline Parameter $^{z}$ & Estimation & Parameter $^{z}$ & Estimation & Parameter $^{z}$ & Estimation \\
\hline$\mu_{1}$ & 0.0167 & $\mu_{52}$ & 3.6143 & $\mu_{66}$ & 3.821 \\
$\mu_{2}$ & 3.95 & $\mu_{53}$ & 3.6143 & $\mu_{67}$ & 3.8207 \\
$\mu_{3}$ & 3.98 & $\mu_{54}$ & 3.6147 & $\mu_{68}$ & 3.821 \\
$\mu_{41}$ & 0.3741 & $\mu_{61}$ & 0.3278 & $\mu_{69}$ & 3.8214 \\
$\mu_{42}$ & 2.8231 & $\mu_{62}$ & 2.7768 & $\delta^{2}$ & 0.0129 \\
$\mu_{43}$ & 3.9125 & $\mu_{63}$ & 3.8207 & $\delta^{2}{ }_{40}$ & 0.1132 \\
$\mu_{44}$ & 3.8981 & $\mu_{64}$ & 3.8662 & $\delta^{2}{ }_{50}$ & 0.2078 \\
$\mu_{51}$ & 3.645 & $\mu_{65}$ & 3.8517 & $\delta^{2}{ }_{60}$ & 0.095 \\
\hline$\mu_{1}, \mu_{2}$ & & &
\end{tabular}

$\overline{z_{1}} \mu_{1}, \mu_{2}$, and $\mu_{3}=$ component distribution of $8 \mathrm{~A}, \mathrm{R} 2-\mathrm{F}_{1}$, and R2; $\mu_{41^{-}}$ $\mu_{44}=$ component distribution of $\mathrm{R} 1-\mathrm{BC}_{1} ; \mu_{51}-\mu_{54}=$ component distribution of $\mathrm{R} 2-\mathrm{BC}_{2} ; \mu_{61}-\mu_{69}=$ component distribution of $\mathrm{R} 2-\mathrm{F}_{2}$; $\delta^{2}=$ error variance; $\delta^{2}{ }_{40}, \delta^{2}{ }_{50}$, and $\delta^{2}{ }_{60}=$ polygenetic variance of components distribution of $\mathrm{R} 2-\mathrm{BC}_{1}, \mathrm{R} 2-\mathrm{BC}_{2}$, and $\mathrm{R} 2-\mathrm{F}_{2}$.

used because of the scarcity of fertility-restoring sources (Zhang et al., 2000b). To use a CMS system, the restoring trait has to be transferred to male parents or inbred lines that possess desirable horticultural traits. However, there is no uniform recognition on how many genes affect restoration-of-fertility. Our previous experiment showed that male parents have been unable to restore the fertility thoroughly, which is unacceptable for $F_{1}$ hybrid plants to set fruit in pepper (Wang et al., 2010). Peterson (1958) and Gulyas et al. (2006) reported that CMS could be restored by a single dominant nuclear gene. In addition, the fertility restorer in sweet pepper was found to be controlled by two complementary genes (Novak et al., 1971). In practice, the restorer-of-fertility does not always manifest as a qualitative character (Wei et al., 2013).

In this study, using the joint segregation analysis, it was concluded that the fertility restorer for CMS in pepper is controlled by two major additive-dominant epistasis genes and additive-dominant epistasis polygenes. Previous studies using four generations also suggested that the fertility restorer is determined by two major additive-dominant epistatic genes and additive-dominant polygenes (Wei et al., 2013). The two investigations provided almost the same results except for the epistatic effect among polygenes. The two independent results suggest that the fertility restorer system was not only controlled by major genes but also affected by polygene although their effect is weaker than that of the major genes. In addition, the environmental variance had relatively fewer effects with a value of 0.0129. These results could support our previous QTL mapping study, in which two major and seven minor QTLs were related to the fertility restorer of CMS (Wei et al., 2017). Wang et al. (2004) identified one major gene and four minor QTLs related to restorer-of-fertility in pepper by QTLs mapping. The similarity between these studies were that both major gene and polygenes determined the fertility restorer, but the significant difference was that there was only one major QTL related to the restorer-of-fertility, whereas our results suggest that there are two major genes or QTLs that determine restorerof-fertility. In cotton, Wang et al. (1996) and Wang and Pan (1997) reported that the CMS could be restored by two dependent dominant genes. Zhang and Stewart (2001a, 2001b) also report that two different dominant genes controlled the restorer-of-fertility characteristic for two main CMS systems. These results for the restorer-of-fertility system are also consistent with these results in which two major genes control 
Table 10. Estimation of genetic parameters in model MX2-ADI-ADI for fertility restorer of 8 A $\times$ R2 pepper progeny.

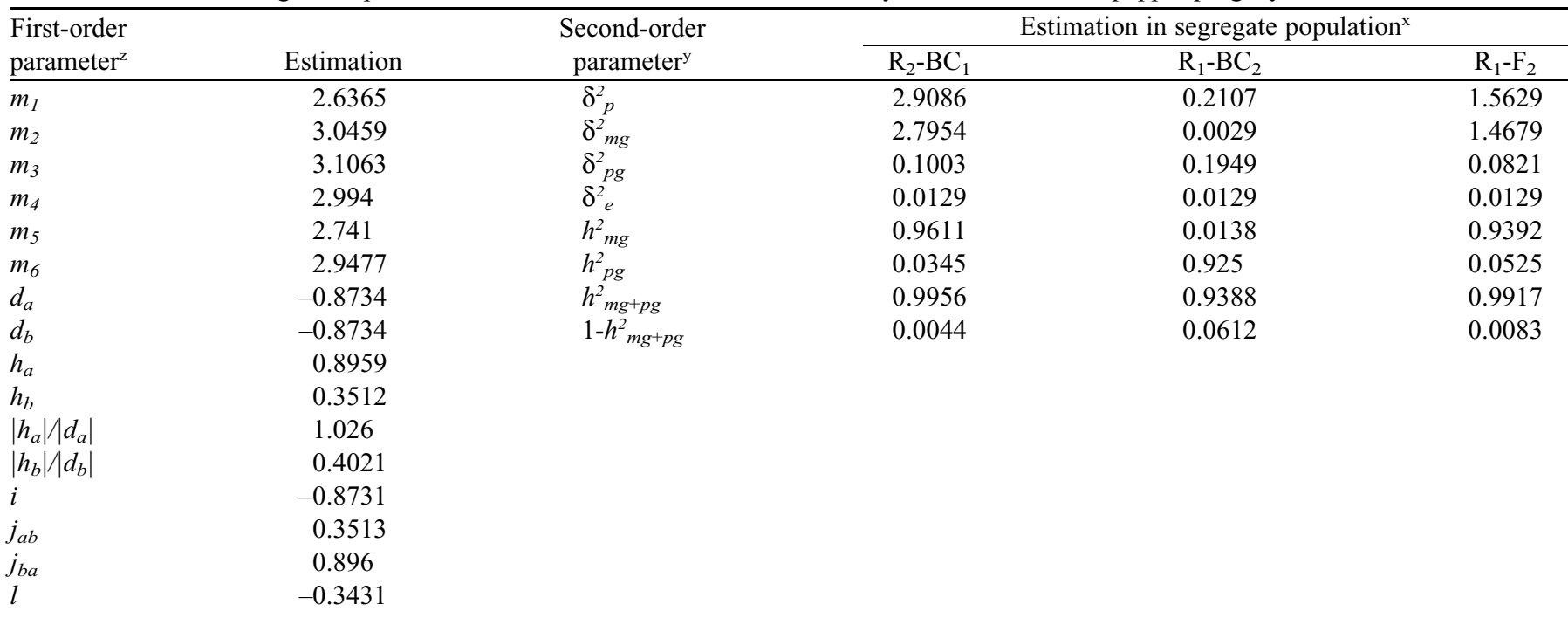

$\overline{\mathrm{z}} m_{1}-m_{6}=$ mean of graduation; $d_{a}=$ additive effects of the first major gene; $d_{b}=$ additive effects of the second major gene; $h_{a}=$ dominant effects of the first major gene; $h_{b}=$ dominant effects of the second major gene; $\left|h_{a}\right| / d_{a} \mid=$ dominant degree of the first gene; $\left|h_{b}\right| / d_{b} \mid=$ dominant degree of the second major gene; $i=$ epistemic effect of additive $\times$ additive between two major gene; $j_{a b}=$ epistatic effect of additive of the first major gene $\times$ dominant of the second major gene; $j_{b a}=$ epistatic effect of additive of the second major gene $\times$ dominant of the first major gene; $l=$ epistemic effect of dominate $\times$ dominant between two major gene.

${ }^{\mathrm{y}} \delta_{p}^{2}=$ phenotypic variance; $\delta^{2}{ }_{m g}=$ main gene variance; $\delta_{p g}^{2}=$ polygene variance; $\delta_{e}^{2}=$ error variance; $h^{2}{ }_{m g}=$ major gene heritability; $h^{2}{ }_{p g}=$ polygene heritability; $h^{2}{ }_{m g+p g}=$ gene heritability; $1-h^{2}{ }_{m g+p g}=$ environmental efficiency.

${ }^{\mathrm{x}} \mathrm{R} 2-\mathrm{BC}_{1}=$ backcross of $\mathrm{R} 2-\mathrm{F}_{1}$ and $8 \mathrm{~B} ; \mathrm{R} 2-\mathrm{BC}_{2}=$ backcross of $\mathrm{R} 2-\mathrm{F}_{1}$ and $\mathrm{R} 2 ; \mathrm{R} 2-\mathrm{F}_{2}=\mathrm{F}_{2}$ generation of $8 \mathrm{~A}$ and $\mathrm{R} 2$.

the trait, and the polygenes with minor effects can be overlooked.

In this study, both progenies had two major genes that play an important role in restoring fertility in the CMS system. Two major genes had equal and high additive value, indicating that the two major genes played the same role in the additive effect. The dominant effect had a greater difference between the two major genes. The first gene had a higher dominant effect and showed over-dominance, whereas the second major gene had little dominance effect, especially in the first set of progeny. The results were similar to previous results except for the additive effects (Wei et al., 2013). This study indicates that both major genes are equally important with respect to their additive effects. On the other hand, when considering dominant effects, maybe only the first major gene is a substantial contributor. Meanwhile, there were interaction effects between the two major genes. The fertility restorer system was considerably affected by an interaction effect. Although there were different values among the four epistatic effects of the two sets of progeny, the major characteristic was the epistatic effect of the additive effect of the second major gene $\times$ the dominant effect of the first major gene. This interaction played the most important epistatic role with the highest value in two progenies, and this should be considered in breeding. However, because the A-lines used in this study were derived from mutagenesis, the results may be true only for the two C-lines that restore fertility in the A-lines; whether these results are applicable to all $\mathrm{C}$-lines requires validation.

\section{Literature Cited}

Akaike, H. 1997. On the entropy maximum principle, p. 27-41. In: P.R. Krishnaiah (ed.). Applications of statistics. North-Holland, Amsterdam, The Netherlands.
Bosland, P.W. and E.J. Votava. 2012. Vegetable and spice capsicums. 2nd ed. CAB International, Wallingford, England.

Bückmann, H., K. Thiele, A. Hüsken, and J. Schiemann. 2014. Influence of air temperature on the stability of cytoplasmic male sterility (CMS) in maize (Zea mays L.). AgBioForum 17:205-212.

Cao, X., B. Liu, and Y. Zhang. 2013. SEA: A software package of segregation analysis of quantitative traits in plants. J. Nanjing Agr. Univ. 36:1-6 [in Chinese].

Chase, C.D. 2007. Cytoplasmic male sterility: A window to the world of plant mitochondrial-nuclear interactions. Trends Genet. 23:81-90.

Elston, R.C. 1984. The genetic analysis of quantitative trait differences between two homozygous lines. Genetics 108:733-744.

Gai, J. and J. Wang. 1998. Identification and estimation of a QTL model and its effects. Theor. Appl. Genet. 97:1162-1168.

Gai, J., Y. Wang, X. Wu, and S. Chen. 2007. A comparative study on segregation analysis and QTL mapping of quantitative traits in plants with a case in soybean. Front. Agric. China 1:1-7 [in Chinese].

Gai, J., Y. Zhang, and J. Wang. 2003. Genetic system of quantitative traits in plants. Science Press, Beijing, China.

Gulyas, G., K. Pakozdi, J.S. Lee, and Y. Hirata. 2006. Analysis of restorer-of-fertility by using cytoplasmic male-sterile red pepper (Capsicum annuum L.) lines. Breed. Sci. 56:331-334.

Hanson, M.R. and S. Bentolila. 2004. Interactions of mitochondrial and nuclear genes that affect male gametophyte development. Plant Cell 16(suppl.):154-169.

Janska, H., R. Sarria, M. Woloszynska, M. Arrieta-Montiel, and S.A. Mackenzie. 1998. Stoichiometric shifts in the common bean mitochondrial genome leading to male sterility and spontaneous reversion to fertility. Plant Cell 10:1163-1180.

Ji, J.J., W. Huang, Y.X. Yin, Z. Li, and Z.H. Gong. 2014. Development of a SCAR marker for early identification of S-cytoplasm based on mitochondrial SRAP analysis in pepper (Capsicum annuum L.). Mol. Breed. 33:679-690.

Kim, D.H., J.G. Kang, and B.D. Kim. 2007. Isolation and characterization of the cytoplasmic male sterility-associated orf456 gene of chili pepper (Capsicum annuum L.). Plant Mol. Biol. 63:519-532. 
Kim, D.H. and B.D. Kim. 2005. Development of SCAR markers for early identification of cytoplasmic male sterility genotype in chili pepper (Capsicum annuum L.). Mol. Cells 20:416-422.

Kim, D.H. and B.D. Kim. 2006. The organization of mitochondrial atp6 gene region in male fertile and CMS lines of pepper (Capsicum annuum L.). Curr. Genet. 49:59-67.

Kumar, R., S. Kumar, N. Dwivedi, S. Kumar, A. Rai, M. Singh, D.S. Yadav, and M. Rai. 2009. Validation of SCAR markers, diversity analysis of male sterile (S-) cytoplasmand isolation of an alloplasmic S-cytoplasm in Capsicum. Scientia Hort. 120:167-172.

Liang, D.N., Q.J. Hu, Q. Xu, X.H. Qi, F.C. Zhou, and X.H. Chen. 2015. Genetic inheritance analysis of melon aphid (Aphis gossypii Glover) resistance in cucumber (Cucumis sativus L.). Euphytica 205:361-367.

Novak, F., J. Betlach, and J. Dubovsky. 1971. Cytoplasmic male sterility in sweet pepper (Capsicum annuum L.). I. Phenotype and inheritance of male sterile character. Zeitschrift fur Pflanzenzüchtung 65:129-140.

Peterson, P.A. 1958. Cytoplasmically inherited male sterility in Capsicum. Am. Nat. 92:111-119.

Shifriss, C. 1997. Male sterility in pepper (Capsicum annuum L.). Euphytica 93:83-88.

Swamy, B.N., N.K. Hedau, C.G.V. Lakshmi Kant, and A. Pattanayak. 2017. CMS system and its stimulation in hybrid seed production of Capsicum annuum L. Scientia Hort. 222:175-179.

Ullah, K., U.N. Khan, R. Gul, S. Gul, M.I. Khan, and I.U. Khan. 2016. Genetic effects for controlling stripe rust (Puccinia striiformis f. sp. tritici) resistance in wheat through joint segregation analysis. Acta Sci. Agron. 38:317-328.

Wang, J. 1996. Studies on identification of major-polygene mixed inheritance of quantitative traits and estimation of genetic parameters. PhD Diss., Nanjing Agr. Univ., Nanjong, China [in Chinese].

Wang, J. and J. Gai. 1997. Identification of major gene and polygene mixed inheritance and estimation of genetic parameters in $\mathrm{F}_{2}$ progeny. Chin. J. Genet. 24:181-190 [in Chinese].

Wang, L., B. Wei, and L. Chen. 2010. The study on selection sestoring line of pepper cytoplasmic male sterile line 8A. China Veg. 6:77-79 [in Chinese].
Wang, L., B. Zhang, V. Lefebvre, S. Huang, A.M. Daubeze, and A. Palloix. 2004. QTL analysis of restorer-of-fertility in cytoplasmic male sterile pepper. Theor. Appl. Genet. 109:1058-1063.

Wang, X. and J. Pan. 1997. Genetic basis of restorer-of-fertility to cytoplasmic male sterile lines available in upland cotton. II. Interactive effects between restorer genes and fertility enhancer gene. Acta Genet. Sin. 24:271-277 [in Chinese].

Wang, X., T. Zhang, and J. Pan. 1996. Genetic basis of restorer-offertility to cytoplasmic male sterile lines available in upland cotton. I. Restorer genes and their effects. Sientica Agriculturae Sinica 29:3240 [in Chinese].

Wei, B., L. Wang, L. Chen, and R. Zhang. 2013. Genetic analysis on the restoration of cytoplasmic male sterility with mixed model of major gene plus polygene in pepper. Acta Hort. Sinica 40:2263-2268 [in Chinese].

Wei, B., L. Wang, R. Zhang, and J. Zhang. 2017. Identification of two major quantitative trait loci restoring the fertility of cytoplasmic male sterility in Capsicum annuum. J. Agr. Biotechnol. 25:43-49 [in Chinese].

Yao, M.H., N. Li, F. Wang, and Z.B. Ye. 2013. Genetic analysis and identification of QTLs for resistance to cucumber mosaic virus in chili pepper (Capsicum annuum L.). Euphytica 193:135-145.

Zhang, B., S. Huang, G. Yang, and J. Guo. 2000b. Two RAPD markers linked to a major fertility restorer gene in pepper. Euphytica 113:155-161.

Zhang, C.J., S.X. Yu, S.L. Fan, J.F. Zhang, and F.G. Li. 2011. Inheritance of somatic embryogenesis using leaf petioles as explants in upland cotton. Euphytica 181:55-63.

Zhang, J. and J.M. Stewart. 2001a. CMS-D8 restoration in cotton is conditioned by one dominant gene. Crop Sci. 41:283-288.

Zhang, J. and J.M. Stewart. 2001b. Inheritance and genetic relationships of the D8 and D2-2 restorer genes for cotton cytoplasmic male sterility. Crop Sci. 41:289-294.

Zhang, Y., J. Gai, and J. Wang. 2000a. Identification of two major genes plus polygene mixed inheritance model of quantitative trait in B1 and B2, and F2. Intl. J. Biomath. 15:358-366. 